\section{THE PATHOLOGY AND SURGERY OF THE VEINS OF THE LOWER LIMB}

By Harold Dodd, Ch.M., F.R.C.S. and Frank B. CocketT, M.S., F.R.C.S. Pp. ix +462 , with $3^{13}$ illustrations. Edinburgh: E. \& S. Livingstone Ltd. 1956. 65s.

Harold Dodd and Frank Cockett are both well known for their contributions to the understanding and treatment of the diseases of the venous system of the lower limbs and a book by them has been awaited with great expectations. The result is even better than one expected and this book can be strongly recommended to all interested in these all too common abnormalities.

Of particular value is the practical aspect of the whole work and nearly every page contains sound advice. This is the best book yet written on this subject.

$$
\text { C.G.R. }
$$

\section{JOINT LIGAMENT RELAXATION treated by

FIBRO-OSSEUS PROLIFERATION

By George Stuart Hacket, M.D., F.A.C.S. Pp. xiv +97 , with 17 illustrations. Oxford: Blackwell Scientific Publications. 1956. 36s.

The author relates the majority of cases of backache to 'relaxation' of the ligaments of the spinal and pelvic joints. 'Relaxation' of ligaments follows accidents or chronic strain.

He has mapped out the areas of referred pain from various ligaments and confirms his diagnosis by abolishing the pain with local anaesthesia.

Treatment is by injection of the ligament with a 'proliferating solution,' which produces scarring in the ligament. Eighty per cent. cures are claimed and many cases have been followed up for ten years or more.

Details of techniques are given.

\section{DISEASES OF THE LIVER}

Edited by Leon Schiff, M.D., Ph.D. Pp. xix + 738, with 244 illustrations. London : Pitman Medical Publishing Co., Ltd. 1956. £5 ros.

This new book is written by a group of collaborators under the editorship of Dr. Leon Schiff of Cincinnati. Each author is especially suited by interest and experience to deal with individual sections and the result is an account of the more important information at present available about diseases of the liver. Contributions include not only those from the United States but also from this country. The book has the advantage that many specialists are describing their particular interests so that varied detailed viewpoints are given. Disadvantages of multiple authorship are that, even with careful editing, there must be overlap of material which adds to the length-and cost-of the book. Some chapters are out of proportion, 67 pages for instance are devoted to toxic hepatitis compared with only 24 on jaundice. The book is beautifullof produced; illustrations are excellent. It can confidently recommended as a reference book to all physicians interested in the liver.

\section{VASCULAR PATTERNS AS RELATED T⿳亠口冋 FUNCTION \\ Second Conference on Microcirculatory Physiology and Pathology}

Reprinted from Angiology, August 1955, Vol.

No. 4. Pp. 136, with 55 illustrations. London Baillière, Tindall \& Cox Ltd. 1956. 205.

This monograph comprises eight papers treating of ' vascular patterns' in minute vessels in generał in the mesentery, skeletal muscle, grafts, endog metrium and placenta, the liver, spleen, humas conjunctiva and the cochlea. All the papers hav in common the endeavour to study vessels in sitito in the living tissue. This is successful in all case with the exception, understandably, of the primate placenta (monkey and human), where Dr. Elizabet f Ramsay has injected with India ink in as fresh state as possible, fixed, serial sectioned and prepared three-dimensional models. In the other cases techniques used include direct microscopy of the human conjuctiva, quartz rod illumination of livers and cochlea (rabbit), exteriorised mesentery an spleen, skin flaps and transparent chambers.

The importance of this monograph is that ${ }_{i}$ comprises records of the functional changes $80 \hat{f}$ living vessels, that it demonstrates differences fren vessel to vessel, that it presents to the reseato worker methods and techniques suitable adaptation to their problems. It is beautifully illustrated. Its weakness is that some of the authors have presented speculations as widespread, generalized conclusions, that in some papero inadequate account is taken of extra-American work. The discussions are interesting but do not seem to be equal to the papers.

A.St.G.H.

\section{PAEDIATRICS FOR THE PRACTITIONER Supplement, 1956}

Edited by WILFRID GAISFORD, M.D., 'M.Sc. F.R.C.P., and Reginald Lightwood, M.D. F.R.C.P., D.P.H. Pp. v + I1 5, with 19 illustra-3 tions. London: Butterworth \& Co. Ltd. I956.0 32s. $6 \mathrm{~d}$.

This supplement contains two original articleso and a brief 'noter-up' to articles in the main volumes.

The account by Lorimer Dods of the physical changes which occur in puberty and adolescence is full of common-sense advice. It is refreshing to seew that a paediatrician with a special interest in endo- 0 crinology, and obviously a considerable scientifieo knowledge of his subject, advises that adolescents ' should be carefully protected from unnecessary? consultations, investigations and treatment and from 